Gut, 1983, 24, 33-37

\title{
Bile salt-induced gastric mucosal damage and histamine receptor antagonists
}

\author{
H J E LEWI and D C CARTER \\ From the University Department of Surgery, Royal Infirmary, Glasgow
}

SUMmaRY The effects of both an $\mathrm{H}_{1}$ receptor antagonist and an $\mathrm{H}_{2}$ receptor antagonist on changes in monovalent ion flux induced by topical sodium taurocholate were studied in antrectomised dogs fashioned with a denervated fundic pouch. The magnitude of taurocholateinduced ion flux was unaffected by topical administration of $\mathrm{H}_{1}$ or $\mathrm{H}_{2}$ receptor antagonists. Parenteral administration of $\mathrm{H}_{1}$ or $\mathrm{H}_{2}$ receptor antagonists given singly or in combination produced an increase in net luminal $\mathrm{Na}^{+}$gain before taurocholate administration but failed to reduce the magnitude of taurocholate-induced ion flux. It is concluded that histamine receptors are unlikely to have a role in the induction of mucosal injury by bile salts.

The gastric mucosal barrier normally restricts movement of $\mathrm{H}^{+}$down a lumen-to-blood concentration gradient of the order of three million-to-one. Disruption of this barrier by agents such as aspirin, ${ }^{1-3}$ ethanol, ${ }^{4}$ or bile salt ${ }^{5}{ }^{6}$ results in an increased loss of $\mathrm{H}^{+}$from the gastric lumen, a net luminal gain of $\mathrm{Na}^{+}$and $\mathrm{K}^{+}$, and an increased movement of fluid into the lumen of the stomach. These changes in monovalent ion flux result from altered mucosal permeability $^{7}$ and continuing exposure to the damaging agent may lead to frank mucosal disruption. ${ }^{8}$

Although histamine $\mathrm{H}_{2}$ receptor antagonists are potent inhibitors of gastric secretion, their effect on mucosal ionic permeability remains controversial. In the canine denervated fundic (Heidenhain) pouch model, neither metiamide nor cimetidine significantly affected bile salt-induced increases in ionic flux. $^{9-12}$ On the other hand, Rees and colleagues ${ }^{10}$ reported that a combination of $\mathrm{H}_{1}$ and $\mathrm{H}_{2}$ receptor antagonisis significantly reduced ion flux after exposure of canine fundic mucosa to bile salt, a finding which was not confirmed by subsequent experiments in chambered segments of canine fundic mucosa,${ }^{13}$ but which was supported by studies in the rat. ${ }^{14}$ The following studies were carried out to reassess the effect of $\mathrm{H}_{1}$ and $\mathrm{H}_{2}$ receptor antagonists given singly or in combination, on bile salt-induced monovalent ion flux in the Heidenhain pouch dog.

Received for publication 7 April 1982

\section{Methods}

\section{MATERIALS}

All experiments were carried out in four male mongrel dogs weighing $15-20 \mathrm{~kg}$ and prepared by antrectomy and construction of a vagallydenervated fundic (Heidenhain) pouch drained to the exterior by a titanium Gregory cannula. Six weeks elapsed between operation and the start of experiments, and during this period the animals were trained to stand quietly on the bench partially supported by two canvas slings suspended from a horizontal bar.

The dogs were denied food but not water for 18 hours before each experiment and at least 48 hours elapsed between experiments. Each experiment consisted of six 30 -minute periods. In each period 20 $\mathrm{ml}$ of isotonic solution $(308 \mathrm{mOsm} / \mathrm{kg}$ ) containing a known concentration of $\mathrm{Na}^{+}$and $\mathrm{H}^{+}$were instilled into the gastric pouch and mixed thoroughly. A $5 \mathrm{ml}$ sample (initial sample) was removed for measurement of $\mathrm{Na}^{+}, \mathrm{K}^{+}$, and $\mathrm{H}^{+}$concentration. After 30 minutes the pouch was emptied and a $5 \mathrm{ml}$ sample (final sample) of fluid was taken for measurement of ion concentration. The pouch was then washed with unlabelled $80 \mathrm{mmol} / \mathrm{l}$ (mequiv/l) $\mathrm{HCl}$ to remove any labelled fluid and allow calculation of the residual volume on completion of each 30-minute period.

During periods $1,2,4,5$, and 6 a standard basal acid solution was instilled into the pouch. Period 3 was used as a test period to instill either (1) taurocholate solution; (2) taurocholate + cimetidine 
solution; or (3) taurocholate + mepyramine solution. Basal acid solution consisted of $80 \mathrm{mmol} / \mathrm{l}$ $\mathrm{HCl}$ made isotonic by addition of appropriate amounts of $\mathrm{NaCl}$. Taurocholate solution contained 5 $\mathrm{mmol} / \mathrm{l}$ (mequiv/l) sodium taurocholate (KochLight, Colnbrook, Bucks.) in $80 \mathrm{mmol} / \mathrm{l} \mathrm{HCl}$ with appropriate adjustment of $\mathrm{NaCl}$ concentration to maintain isosmolality. To enable accurate measurement of volume changes each litre of basal or taurocholate solution contained $1 \mathrm{~g}$ polyethylene glycol (MW 4000) and $0 \cdot 1 \mathrm{ml}{ }^{14} \mathrm{C}$-polyethylene glycol (MW 4000 New England Nuclear, Boston, Mass.) from a stock solution containing $50 \mu \mathrm{Ci} / \mathrm{ml}$.

Taurocholate plus cimetidine solution consisted of $200 \mathrm{mg}$ cimetidine (Smith, Kline and French Ltd, Welwyn Garden City) dissolved in $20 \mathrm{ml}$ taurocholate solution. Taurocholate plus mepyramine solution consisted of $100 \mathrm{mg}$ mepryamine maleate (Boots Ltd, Nottingham) dissolved in $20 \mathrm{ml}$ taurocholate solution.

Histamine receptor antagonists were administered parenterally as an intramuscular injection of mepyramine maleate $(10 \mathrm{mg} / \mathrm{kg})$ at the beginning of period 1 , as an intravenous infusion of cimetidine (100 mg/h; concentration $100 \mathrm{mg} / 25 \mathrm{ml}$ saline) starting at the beginning of period 1 for the duration of the study, or as a combination of the two agents.

Initial and final samples were measured for $\left\{\mathrm{Na}^{+}\right\}$ and $\left\{\mathrm{K}^{+}\right\}$concentration using a digital flame photometer (Corning 435 flame photometer). $\left\{\mathrm{H}^{+}\right\}$ concentration was measured using an automatic titrator (Radiometer pHM62, Radiometer, Copenhagen). The amount of $0 \cdot 1 \mathrm{~N} \mathrm{NaOH}$ required to bring the sample to $\mathrm{pH} 7.0$ was determined, and a 1 $\mathrm{ml}$ aliquot of the derived neutral solution was added to $10 \mathrm{ml}$ of scintillant (Mini RIA, Koch-Light, Colnbrook, Bucks) and $\mathrm{C}^{14}$ activity determined by scintillation counting in a Packard Tricarb 2660 liquid scintillation counter (Packard Instruments Co Inc, Downers Grove, Illinois). Knowing the volume instilled at the start of each period (Vi) and the amount of $0.1 \mathrm{~N} \mathrm{NaOH}$ needed to achieve neutrality, measurement of $\mathrm{C}^{14}$ activity at the end of the 30-minute period allowed calculation of the final volume $\left(V_{f}\right)$ of fluid in the pouch at the end of each 30-minute period:

$$
\left(V_{f}\right)=\left(V_{i}\right)\left(\mathrm{cpm}_{\mathrm{i}} / \mathrm{cpm}_{\mathrm{f}}\right)
$$

where $\mathrm{cpm}_{\mathrm{i}}$ and $\mathrm{cpm}_{\mathrm{f}}$ are the specific activity of ${ }^{14} \mathrm{C}$ PEG in counts/min in the initial and final samples respectively.

Changes in ion mass $(\mu \mathrm{mol} / 30 \mathrm{~min})$ could then be calculated as:

$$
\text { change in mass }=\left(\mathrm{V}_{\mathrm{f}}\right)\left(\mathrm{C}_{\mathrm{f}}\right)-\left(\mathrm{V}_{\mathrm{i}}\right)\left(\mathrm{C}_{\mathrm{i}}\right)
$$

where $C_{f}$ and $C_{i}$ are the concentrations of the ion in the final and initial samples respectively.
STATISTICAL ANALYSIS

The effect of topical taurocholate on net ion flux was determined by comparing periods 2 and 3 in terms of net changes in ion mass. The significance of observed differences was assessed by the paired $t$ test.

The effect of histamine receptor antagonists was assessed by comparing periods during control tests (taurocholate alone) with the comparable periods involving the administration of histamine receptor antagonists. The significance of observed differences was assessed by the non-paired $t$ test.

\section{Results}

\section{TOPICAL TAUROCHOLATE}

Changes in net flux after exposure of fundic mucosa to $5 \mathrm{mM}$ sodium taurocholate solution for a 30 minute period are illustrated in Fig. 1. Exposure to taurocholate solution significantly increased net $\mathrm{H}^{+}$
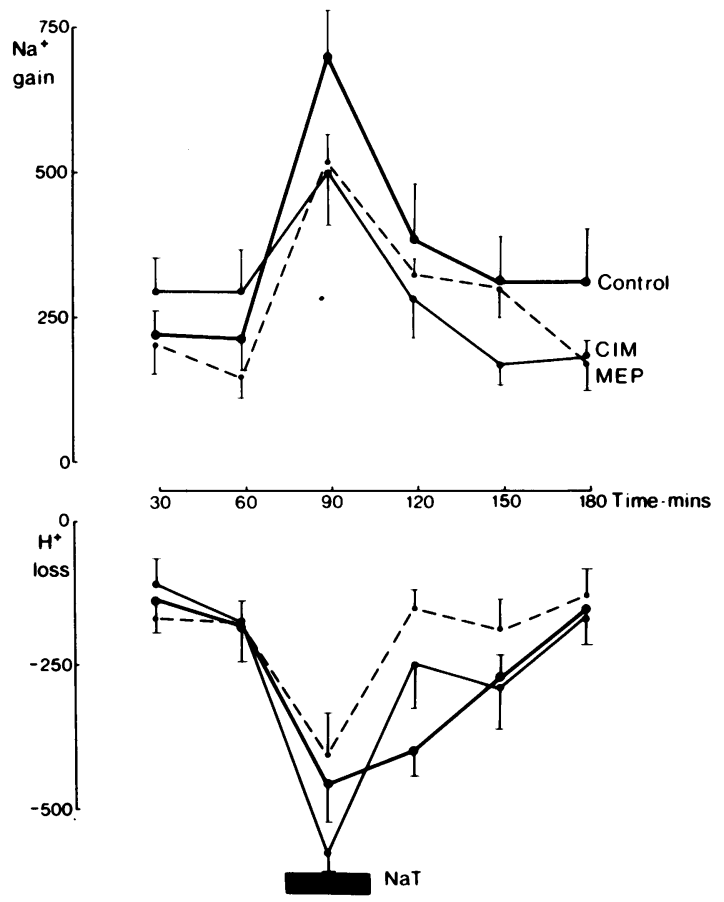

Fig. 1 Changes in net luminal $\mathrm{Na}^{+}$gain and $\mathrm{H}^{+}$loss ( $\mu \mathrm{mol} 30 / \mathrm{min}$ ) in canine fundic pouches after topical application of acid taurocholate solution alone (control), acid taurocholate solution plus $200 \mathrm{mg}$ cimetidine (CIM), and acid taurocholate solution plus $100 \mathrm{mg}$ mepyramine maleate $(M E P)$. Results are the mean $\pm S E M$ of two experiments in each of four dogs. 
loss from $-185 \pm 30$ to $-454 \pm 94 \mu \mathrm{mol} / 30 \mathrm{~min}$ $(\mathrm{p}<0.05)$, and increased net gain of $\mathrm{Na}^{+}$from $209 \pm 56$ to $692 \pm 107 \mu \mathrm{mol} / 30 \mathrm{~min}(\mathrm{p}<0 \cdot 01)$. Net $\mathrm{K}^{+}$ gain increased from $10 \pm 3$ to $31 \pm 7 \mu \mathrm{mol} / 30 \mathrm{~min}$ $(\mathrm{p}<0.05)$, and the net luminal volume rose from $3 \cdot 2 \pm 0 \cdot 8$ to $4 \cdot 4 \pm 0.4 \mathrm{ml} / 30 \mathrm{~min}(\mathrm{NS})$.

\section{TOPICAL TAUROCHOLATE AND TOPICAL} HISTAMINE RECEPTOR ANTAGONISTS

Addition of either mepyramine maleate or cimetidine to topical taurocholate solution produced no significant effect on net ion flux or net fluid gain (Fig. 1) when compared with changes observed after exposure to topical taurocholate alone.

\section{TOPICAL TAUROCHOLATE AND SINGLE}

PARENTERAL HISTAMINE RECEPTOR ANTAGONIST Intramuscular injection of mepyramine maleate had no significant effect on net $\mathrm{H}^{+}$flux either before or during exposure of the pouch to topical taurocholate solution, but was associated with a prolonged and significant increase in net $\mathrm{H}^{+}$loss $(\mathrm{p}<0.05)$ after removal of the taurocholate solution (Fig. 2, Table). Mepyramine maleate injection was also associated with a significant increase in net $\mathrm{Na}^{+}$gain in periods 1-3 relative to control experiments $(p<0.05$ for periods 1,2 , and 3 ) and was accompanied by a significant gain in volume after exposure to topical taurocholate in period $3(\mathrm{p}<0 \cdot 05)$.

Cimetidine infusion had no effect on net $\mathrm{H}^{+}$loss either before or after exposure of the pouch to topical taurocholate solution. $\mathrm{Net} \mathrm{Na}^{+}$gain in periods 1 and 2 during cimetidine infusion was significantly greater than control $(p<0.05$ for both periods) but thereafter net $\mathrm{Na}^{+}$gain did not differ significantly from control values.

\section{TOPICAL TAUROCHOLATE AND COMBINATION} OF PARENTERAL HISTAMINE ANTAGONISTS Combination of intramuscular mepyramine maleate and intravenous cimetidine was associated with a significant early increase in net $\mathrm{Na}^{+}$gain $(\mathrm{p}<0.01)$
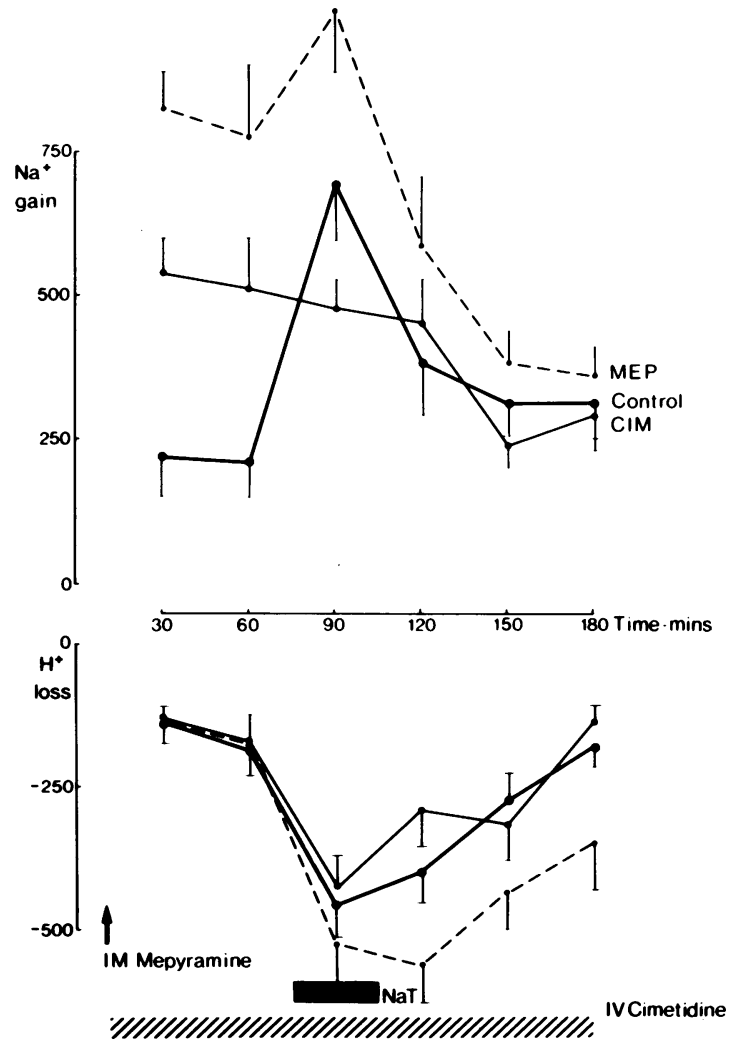

Fig. 2 Changes in net luminal $\mathrm{Na}^{+}$gain and $\mathrm{H}^{+}$loss ( $\mu \mathrm{mol} / 30 \mathrm{~min}$ ) in canine fundic pouches after topical application of acid taurocholate solution alone (control) or with bolus injection of mepyramine maleate $(10 \mathrm{mg} / \mathrm{kg}$; $M E P)$ or intravenous infusion of cimetidine $(100 \mathrm{mg} / \mathrm{h}$; CIM). Results are the mean $\pm S E M$ of two experiments in each of four dogs.

Table Efect of $\mathrm{H}_{1}$ and $\mathrm{H}_{2}$ receptor antagonists on net ion flux ( $\mu \mathrm{mol} / 30 \mathrm{~min}$ ) and volume gain ( $\left.\mathrm{ml} / 30 \mathrm{~min}\right)$

\begin{tabular}{|c|c|c|c|c|}
\hline & Net $H^{+}$loss & Net $\mathrm{Na}^{+}$gain & Net $K^{+}$gain & Volume gain \\
\hline $\begin{array}{l}5 \text { mmol ATS alone } \\
\text { + Topical cimetidine } \\
\text { + Topical mepyramine } \\
\text { + IV cimetidine } \\
\text { + IM mepyramine } \\
\text { + IV cimetidine and IM mepyramine }\end{array}$ & $\begin{array}{l}-454 \pm 94 \\
-579 \pm 100 \\
-397 \pm 68 \\
-427 \pm 158 \\
-527 \pm 129 \\
-554 \pm 133\end{array}$ & $\begin{array}{l}696 \pm 107 \\
494 \pm 117 \\
504 \pm 15 \\
466 \pm 52 \\
990 \pm 129 * \\
612 \pm 91\end{array}$ & $\begin{array}{l}32 \pm 7 \\
28 \pm 9 \\
29 \pm 9 \\
13 \pm 3 \\
35 \pm 6 \\
26 \pm 9\end{array}$ & $\begin{array}{l}4 \cdot 4 \pm 0 \cdot 4 \\
3 \cdot 5 \pm 0 \cdot 4 \\
5 \cdot 1 \pm 2 \cdot 3 \\
3 \cdot 2 \pm 0 \cdot 5 \\
7 \cdot 1 \pm 1 \cdot 1^{*} \\
3 \cdot 8 \pm 1\end{array}$ \\
\hline
\end{tabular}

Data referred to changes observed during period 3 of exposure of canine fundic mucosa to $5 \mathrm{mM}$ acid taurocholate solution. Results derived from mean of two experiments in each of four dogs $( \pm S E M)$.

${ }^{*} \mathbf{p}<0.05$. 
when compared with control values, but net $\mathrm{H}^{+}$loss was not affected. The combination of agents had no effect upon the magnitude of net $\mathrm{Na}^{+}$or $\mathrm{H}^{+}$flux during or after exposure to topical taurocholate solution (Fig. 3).

\section{Discussion}

The present study shows that topical administration of $\mathrm{H}_{1}$ or $\mathrm{H}_{2}$ receptor antagonists has no significant effect on net monovalent ion flux induced by $5 \mathrm{mM}$ sodium taurocholate solution in canine fundic mucosa. Given parenterally each agent produced an increase in net luminal $\mathrm{Na}^{+}$gain before taurocholate instillation, and, in the case of mepyramine maleate, this increase was prolonged. Parenteral mepyramine also prolonged net $\mathrm{H}^{+}$loss after taurocholate instillation, whereas parenteral cimetidine had no effect. Combination of parenteral mepyramine and cimetidine did not significantly affect the magnitude
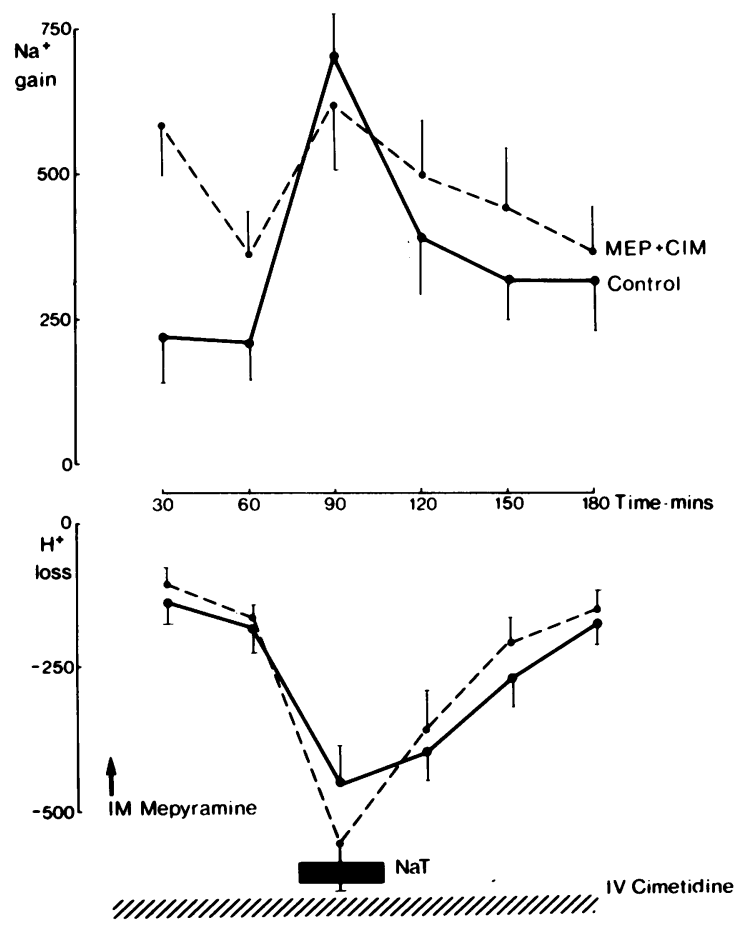

Fig. 3 Changes in net luminal $\mathrm{Na}^{+}$gain and $\mathrm{H}^{+}$loss ( $\mu \mathrm{mol} 30 / \mathrm{min}$ ) in canine fundic pouches after topical application of acid taurocholate solution alone (control) or with bolus injection of mepyramine maleate $(100 \mathrm{mg} / \mathrm{kg})$ combined with intravenous infusion of cimetidine (100 $m g / h)(M E P+C I M)$. Results are the mean \pm SEM of two experiments in each of four dogs. of net $\mathrm{Na}^{+}$or net $\mathrm{H}^{+}$flux during exposure of the fundic mucosa to taurocholate but was associated with an increase in net luminal $\mathrm{Na}^{+}$gain before taurocholate instillation.

These observations relating to the effect of $\mathrm{H}_{2}$ receptor antagonists on bile salt-induced flux are in general agreement with those reported earlier from our own laboratory ${ }^{9} 12$ and by others. ${ }^{10} 11$ The significance of the increased net luminal $\mathrm{Na}^{+}$gain observed when cimetidine was infused before taurocholate instillation is uncertain, but our previous study with cimetidine showed a similar pattern, the difference failing to reach statistical significance. ${ }^{12}$

Failure of the combination of $\mathrm{H}_{1}$ and $\mathrm{H}_{2}$ receptor antagonists to affect bile salt-induced net flux significantly is in keeping with results reported by Cheung and Porterfield, ${ }^{13}$ but is at variance with those reported by Rees and colleagues. ${ }^{10}$ Although both studies used a similar model, the Rees study differs from our own in a number of important respects. Rees and colleagues ${ }^{10}$ stress that they selected a concentration of taurocholate for each dog which produced consistent but 'minimal' damage. While the concentrations used induced only small changes in net flux, they ranged in concentration from $16-24 \mathrm{mM}$ as opposed to $5 \mathrm{mM}$ in the present study. This difference in susceptibility to permeability change may be due in part to differences between dogs, but may relate to the fact that Rees and colleagues ${ }^{10}$ did not use a volume marker to correct for incomplete volume recovery, and so allow accurate estimation of changes in luminal ion mass. ${ }^{15} 16$ In our experience, the percentage volume recovery of fluid instilled into Heidenhain pouches varies in individual animals from $76-91 \%$ (mean of six dogs $83 \%$ ), a finding in broad agreement with that of others. ${ }^{17} 18$ Furthermore, it cannot be assumed that residual pouch volume remains constant for the duration of an experiment. Our experience is in agreement with that of Bloom and associates ${ }^{18}$ in that cumulative residual volume may double or even treble in the course of such studies. Other differences between the Rees study and our own include their use of a slightly greater luminal $\mathrm{H}^{+}$concentration (100 $\mathrm{mmol} / \mathrm{l})$ and administration of metiamide rather than cimetidine.

It has been postulated that intramucosal histamine release is implicated in gastric mucosal damage after disruption of the permeability barrier, ${ }^{3} 19$ and histamine appears to increase mucosal ionic permeability in dogs ${ }^{20}$ Histamine $\mathrm{H}_{1}$ and $\mathrm{H}_{2}$ receptors subserving vasodilatation have been defined in the submucosal arterioles of the corpus and antrum of the cat and rat stomach. ${ }^{2122}$ The vasodilator response to histamine is dose- 
dependent and, in the corpus, $\mathrm{H}_{1}$ and $\mathrm{H}_{2}$ receptor antagonists are equally effective inhibitors of the response to histamine. While care must be exercised in extrapolating these results to other species, mepyramine and cimetidine given alone or in combination might be expected to antagonise the vasodilator effects of any histamine liberated during bile salt-induced mucosal damage in the present experiments. In the event, neither agent affected bile salt-induced increase in net $\mathrm{Na}^{+}$or $\mathrm{H}^{+}$flux when given topically (Fig. 1) or when given parenterally in combination (Fig. 3), suggesting that under these experimental conditions histamine does not influence ionic permeability regardless of any effect on the submucosal vasculature. When given singly by the parenteral route, neither antagonist affected the magnitude of net $\mathrm{H}^{+}$loss during exposure to bile salt and the significance of the prolonged net $\mathrm{H}^{+}$loss after exposure to mepryamine (Fig. 2) is uncertain. The effect of both agents on net $\mathrm{Na}^{+}$flux before bile salt instillation is difficult to explain. In that these changes were not accompanied by increases in net $\mathrm{H}^{+}$loss or consistent increases in fluid volume, they are unlikely to reflect changes in gastric mucosal permeability to monovalent ions or changes in the rate of nonpariental secretion.

In conclusion, the present experiments have failed to show any effect of $\mathrm{H}_{1}$ or $\mathrm{H}_{2}$ receptor antagonists, given singly or in combination, on the magnitude of bile salt-induced ionic flux across canine fundic gastric mucosa. While it is accepted that increased ionic permeability is not the sole determinant of mucosal damage, and that gastric mucosal blood flow may have critical importance in this context, we agree with Cheung and Porterfield ${ }^{13}$ that histamine is unlikely to mediate bile salt-induced mucosal injury.

During the course of these studies HJEL was supported by the Wellcome Trust. The financial support of Smith, Kline and French Ltd is gratefully acknowledged, as is the technical and secretarial assistance of $\mathrm{Mr}$ Robert Wright, Mrs Linda Middleton, Miss Anne McKellar, and Mrs Mary Baird.

\section{References}

1 Davenport HW. Gastric mucosal injury by fatty acids and acetylsalicylic acid. Gastroenterology 1964; 46: 245-53.

2 Davenport, HW. Damage to gastric mucosa: effects on salicylates and stimulation. Gastroenterology 1965; 49: 189-96.
3 Davenport HW. Salicylate damage to the gastric mucosal barrier. $N$ Engl J Med 1970; 276: 1307-12.

4 Davenport HW. Ethanol damage to canine oxyntic glandular mucosa. Proc Soc Exp Biol Med 1967; 126: 657-62.

5 Davenport HW. Destruction of the gastric mucosal barrier by detergents and urea. Gastroenterology 1968; 54: 175-81.

6 Black RB, Hole D, Rhodes J. Bile damage to the gastric mucosal barrier: the influence of $\mathrm{pH}$ and bile acid concentration. Gastroenterology 1971; 61: 178-84.

7 Chung RSK, Field M, Silen W. Effects of methyl prednisolone on hydrogen ion back diffusion in the canine stomach. J Clin Invest 1978; 62: 262-70.

8 Kelly DG, Code CF, Lechago J, Bugajski J, Schlegel JF. Physiological and morphological characteristics of progressive disruption of the canine gastric mucosal barrier. Dig Dis Sci 1979; 24: 424-41.

9 O'Brien P, Carter DC. Effect of gastric secretory inhibitors on the gastric mucosal barrier. Gut 1975; 16: 437-42.

10 Rees WDA, Rhodes J, Wheeler MH, Meek EM, Newcombe RG. The role of histamine receptors in the pathophysiology of gastric mucosal damage. Gastroenterology 1977; 72: 67-71.

11 Gurll NJ, Zinner MJ, Callahan W. Effect of histamine $\mathrm{H}_{2}$ antagonism by metiamide on the response of the canine gastric mucosa to acid and bile salt. Gastroenterology 1977; 73: 255-9.

12 Kenyon GS, Ansell IE, Carter DC. Cimetidine and the gastric mucosal barrier. Gut 1977; 18: 631-5.

13 Cheung LY, Porterfield G. Is histamine a mediator of bile induced gastric mucosal injury? J Surg Res 1978; 24: 272-6.

14 Bommelaer G, Guth PH. Protection by histamine receptor antagonists and prostaglandin against gastric mucosal barrier disruption in the rat. Gastroenterology 1979; 77: 303-8.

15 Fordtran JS. Marker perfusion techniques for measuring intestinal absorption in man. Gastroenterology 1966; 51: 1089-93.

16 Soergel KH. Inert markers. Gastroenterology 1968; 54: 449-52.

17 Worning H, Amdrup E. Experimental studies on the value of the reference substances, polyethyleneglycol, bromsulphthalein, and ${ }^{51} \mathrm{Cr}$ as indicators of the fluid content in the intestinal lumen. Gut 1965; 6: 487-93.

18 Bloom DS, Jacobson ED, Grossman MI. Validation of dilution indicators in the stomach. Gastroenterology 1967; 52: 205-10.

19 Johnson LR, Overholt BF. Release of histamine into gastric venous blood following injury by acetic or salicylic acid. Gastroenterology 1967; 52: 505-10.

20 Moody FG, Davis WL. Hydrogen and sodium permeation of canine gastric mucosa during histamine and thiocyanate administration. Gastroenterology 1970; 59: 350-7.

21 Guth PH, Smith E. Histamine receptors in the gastric micro-circulation. Gut 1978; 19: 1059-63.

22 Guth PH, Moler TL, Smith E. $\mathrm{H}_{1}$ and $\mathrm{H}_{2}$ histamine receptors in rat gastric submucosal arterioles. Microvasc Res 1980; 19: 320-8. 